\title{
Política nos Estados Unidos: Tendências nas últimas quatro décadas
}

\section{BERT A. ROCKMAN}

$\mathrm{N}$ as últimas quatro décadas, entre 1953 e 1993, a despeito das grandes mudanças, houve muita estabilidade. Essa estabilidade deve-se à estrutura constitucional, organizada de modo a dificultar a formação de maiorias politicamente ativas. $O$ sistema de governo dos Estados Unidos apresenta numerosos aspectos que impedem a policy making *. Está organizado para dificultar o exercício da liderança central e permitir o acesso público à autoridade governamental. Como resultado torna-se relativamente fácil influenciar o governo a nũo agir em determinadas situaçóes. $O$ sistema governamental americano estrutura-se em torno de um processo, extremamente complexo, de responsabilidade (accountability) das decisóes políticas, e é especialmente concebido para ser sensível aos interesses locais. A natureza do sistema eleitoral e a forte expectativa, nos Estados Unidos, de que os representantes eleitos precisam ser hábeis em atender seu eleitorado, faz com que os primeiros fiquem muito expostos e vulneráveis politicamente. Portanto, os políticos americanos tendem a fazer o que deve ser feito a fim de reduzir sua vulnerabilidade. Isso significa correr o menor risco possível evitando se expor a conseqüências políticas fatais.

Universalmente, uma das mais recentes características da política é a ubiqüidade dos meios de comunicação de massa. Desempenham importante papel, promovendo o fórum pelo qual se realiza a teia política (relaçôes públicas). Realmente, a cobertura de notícias pelas redes nacionais dedica pouco tempo à mensagem do candidato e faz com que as imagens visuais e os fragmentos de som se tornem cada vez mais importantes à percepção do público. A capacidade de gerar uma mensagem coerente, principalmente através da rede de televisão, diminuiu. Por isso, na propaganda política realizada através dos meios de comunicação eletrônica, o curto espaço de tempo e os fragmentos sonoros ou

* Comumente o termo policy making é usado em portugués em sua forma original. Refere-se aos processos de execuçáo das políticas públicas. (N.T.) 
visuais convergem de tal forma que se torna fácil atacar e difícil defender qualquer comportamento potencialmente impopular que exija uma justificativa complexa. Portanto, todo político deve estar ciente de que qualquer posiçáo ou atitude particular por ele tomada, quando reduzida a uma breve apresentação televisiva ou radiofônica, poderá ser utilizada, pelo adversário, para caracterizar um slogan de ataque. Assim, durante os períodos eleitorais, os políticos precisam conscientizar-se de seus pontos vulneráveis quando forem atacados pelos adversários de outros partidos. Não devem negligenciar o fato de que, muitas vezes, açóes e palavras poderão ser usadas contra sua própria pessoa em eleiçóes primárias, quando os ataques vierem de dentro do próprio partido. $O$ mais temido por esses políticos é, sobretudo, que uma aparência de vulnerabilidade possa causar sérios ataques $e$, por isso, tentam incansavelmente evitar que suas fraquezas transpareçam. Com relaçăo a tais inseguranças é que se desenvolve a possibilidade de permanência na carreira política.

Há um interessante paradoxo nessa situação. Por que detentores de cargos públicos eletivos devem estar sempre táo atentos para que suas palavras e açóes não possam ser usadas contra sua própria pessoa? Afinal, quando se observa o nível de retorno eleitoral entre os membros do Congresso americano, tanto no Senado quanto na Câmara dos Deputados, principalmente na última, esse nível é muito elevado. Na Câmara dos Deputados essa taxa geralmente atinge acima de $90 \%$ e é comum ultrapassar $95 \%$. Um dos principais motivos dessa ocorrência é que esses representantes despendem muito tempo tentando evitar eventuais ataques políticos. Em virtude desse comportamento cauteloso, os membros do Congresso garantem sua invulnerabilidade (1). Essa atitude gera alto nível de individualismo político nos Estados Unidos e, nesse aspecto, é possível que os Estados Unidos se assemelhem ao Brasil. $O$ resultado é que se torna especialmente difícil unir maiorias em torno de políticas que tenham custos diretos e visíveis (2). É provável que, nos dias atuais, os políticos com cargos eletivos confiem menos em sua capacidade de autodefesa $e$, assim, comportem-se de modo a diminuir as chances de se exporem a riscos.

Bom exemplo de como pode ser difícil construir maiorias sob tais circunstâncias pode ser retirado dos acontecimentos que geraram a aprovação, por margem muito estreita de votos, da lei orçamentária de 1993 do governo Clinton. Entre outros, o projeto de lei continha novos dispositivos com relação a impostos e a corte de gastos. Esses eram quase todos controversos. A lei foi aprovada por 218 a 216 votos na Câmara dos Deputados e, no Senado, dividido ao meio, 50 a 50, com o voto de desempate dado pelo vice-presidente. A estreiteza dessas margens de votaçáo é notável, uma vez que o partido do presidente mantém, clara- 
mente, maiorias substanciais em ambas as câmaras. Nenhum republicano em qualquer das duas Câmaras votou a favor do projeto de lei do presidente. O público estava dividido sobre a proposta. A maioria das pesquisas evidenciava forte divisão do sentimento geral da população. $O$ partidarismo foi quase tão impressionante na ala dos Democratas quanto na dos Republicanos e o preço para a negociaçăo da vitória final foi alto. Nessa situaçáo, a Casa Branca, a fim de conseguir os votos decisivos precisou adular, persuadir e finalmente fazer concessões. Entretanto, o concedido a uma ala do partido ou a um de seus membros gerou pressōes contrárias no interior do próprio partido do presidente. $O$ individualismo do Congresso estava em perfeito sincronismo com o seu partidarismo. Por trás disso o senador Bob Kerrey, o último oposicionista do Partido Democrático, antes de apoiar uma versão modificada do projeto de Clinton, ameaçadoramente declarou: "Não há consenso no país sobre o que devemos fazer para se alcançar o crescimento econômico. Alguém tem que aceitar receber menos impostos e alguém precisa pagar as contas" (3).

Evidentemente, se o plano orçamentário criou complicaçóes e impasse político, como aconteceu, o plano de saúde previdenciária, proposto pelo presidente, depara-se com um caminho mais tortuoso por ser mais complexo do que o plano orçamentário, finalmente aprovado. Pois, apesar de haver apoio da maioria às reformas do atual sistema, não há maioria sequer para uma única opção. Quando há redistribuiçăo de benefícios, alguém, por definição, perderá algo. Todos, evidentemente, querem solucionar o problema público às custas dos demais.

Assim, existem paradoxos nas mudanças que ocorreram nos EUA. A mudança em uma direçáo pode ser contrabalançada por forças atuantes vindas da direçáo oposta. Percebemos pelo episódio das contas orçamentárias, por exemplo, que o individualismo no Congresso e o partidarismo cresceram ao mesmo tempo. Observamos, também, o quanto é difícil receber apoio político quando os que saem perdendo na redistribuiçáo são claramente indentificáveis. A capacidade de mascarar tais perdas também desapareceu.

\section{Comparando o cenário político: 1953-93: alinhamentos políticos e grande público}

Há quarenta anos atrás, Dwight Eisenhower foi o primeiro presidente republicano dos EUA. Depois de vinte anos, reeleito em 1956 por grande maioria, seu governo foi considerado como exceçáo - caso raro ou deslocado. De acordo com a crença geral, os republicanos ganharam a presidência em 1952, em razão das qualidades pessoais de seu líder. 
Eisenhower não foi um político comum, ao contrário, alcançou o status de um ícone como comandante das forças aliadas na Europa, durante a Segunda Guerra Mundial. Além disso, Eisenhower era reconhecido particularmente como uma figura não partidária, imagem esta que constantemente cultivava (4). Os Democratas, na verdade, tentaram recrutá-lo para disputar a presidência em 1948, por acreditarem que o senhor Truman não poderia ganhar a eleição. Há quarenta anos julgava-se normal ou natural haver uma maioria Democrata, uma vez que ela fora forjada nos anos $\mathbf{3 0}$ pela coalizão do New Deal de Franklin Roosevelt. Da mesma forma, em 1953, os Republicanos detinham pequena maioria nas duas Câmaras do Congresso, fato que ocorreu apenas duas vezes em 24 anos. É interessante notar ter sido essa a última vez que os Republicanos possuíram a maioria em ambas as Câmaras.

Em 1953, a idade mínima para votar era 21 anos, hoje é 18. Em 1953, na maioria dos estados do sul, a admissáo dos negros como eleitores ainda era limitada e a segregação racial formal prevalecia nos estados sulinos, nos antigos estados confederados e em muitos dos chamados estados limítrofes (borders states), ou seja, os estados vizinhos àquela antiga confederação.

Nos Estados Unidos, na época em pauta, os partidos possuíam estrutura fortemente organizada localmente mas muito fraca nacionalmente. Em outras palavras, a base de sua organizaçáo era essencialmente local e náo nacional. As coalizóes internas dentro de cada partido e, em especial, entre os Democratas, eram repletas de contradiçốes. À época, o eleitorado Democrata era composto por intelectuais de esquerda, máquina local urbana das organizações patronais, minorias raciais no norte, segregacionistas sulinos, sindicatos de trabalhadores e grupos étnicos europeus. Excetuando a maioria dos antigos pequenos povoamentos mexicanos no estado do Novo México e na cidade de San Antonio, as grandes migraçóes latinas, especialmente as do Caribe e da América Central e a dos negros do Caribe ainda não haviam ocorrido, bem como, ainda náo se processara a mais nova migração asiática.

O eleitorado Republicano era relativamente mais simples, mas, também, possuía suas contradiçóes. A principal delas dentro do partido havia sido um conflito ocorrido entre Wall Street e Main Street. Em outras palavras, os Republicanos geralmente detinham uma maioria natural dentre a chamada população de origem inglesa protestante. Hoje, porém, todos os grupos étnicos europeus sáo algumas vezes designados como anglos, (prova da crescente diversidade da população americana de origem não-européia). Há quatro décadas atrás, essa classificação referia-se essencialmente à antiga população das Ilhas Britânicas $e$, até 
certo ponto, da Alemanha ou de outros países nórdicos. O conflito entre o eleitorado Republicano girava em torno das pequenas cidades americanas e os centros financeiros, principalmente Wall Street em Nova Iorque. Sem dúvida, o fundamentalismo religioso era mais incisivo na sociedade americana daquela época do que atualmente, mas menos penetrante como força ou problema político. Os fundamentalistas religiosos da atualidade representam eleitorado importante para o partido Republicano, em especial para os ativistas do partido.

Em 1953, as barreiras à participação eram mais fortes do que hoje; registrar-se para ser eleitor nấo era procedimento fácil. Os impedimentos eram colocados, principalmente nos estados do sul, aos negros. Essas mesmas dificuldades apresentadas aos negros eram impostas aos brancos com baixa renda e pouca escolaridade. Nos locais onde a participação dos negros foi suprimida, também a participação dos brancos era menor. Em geral, havia empenho relativamente pequeno em atrair novas pessoas para o interior do sistema, salvo quando houvesse, para tanto, uma razão política determinada. A máquina política urbana, por exemplo, tinha motivo para agir dessa forma e, de fato, embora passivamente, tentou trazer mais indivíduos, em geral imigrantes, para dentro do sistema político.

Entre 1952 e 1968, o comparecimento às urnas nas eleiçóes presidenciais foi regularmente mantido entre 60 - 65\%. Na eleição de 1972, esse índice caiu abaixo de $60 \%$, ao mesmo tempo em que admitiram-se como eleitores os maiores de 18 anos. Antes do aumento do número de eleitores, ocorrido em 1992, entre 1976 e 1988, as taxas de comparecimento de votantes para as eleiçóes presidenciais chegaram a baixar para $53-55 \%$ (5). Em outras palavras, nesses 40 anos tem havido queda constante da participação política da populaçáo no processo eleitoral. Simultanemente, entretanto, vem se expandindo o número de eleitores e desenvolvendo-se uma nacionalizaçáo da organizaçáo do partido, embora, também tenha sido percebido declínio da confiança do público.

\section{O congresso}

Há 40 anos, os líderes de partido no Congresso eram figuras poderosas, em especial os do Partido Democrático, mas possuíam, como tal, poder formal relativamente pequeno. Os líderes do Partido Democrático eram Lyndon Johnson, líder dos Democratas no Senado, que veio a ser presidente e Sam Rayburn, líder da bancada Democrática na Câmara dos Deputados e que, após as eleiçóes de 1954, seria novamente presidente da Câmara (posto normalmente ocupado pelo líder da maioria). Johnson e Rayburn eram personalidades fortes e foram, nesse sen- 
tido, figuras políticas muito interessantes, apesar de terem pouco poder formal à sua disposição. Tal poder recaía sobre as comissōes do Congresso e, especialmente, sobre os seus presidentes. $O$ poder náo residia entre os líderes, e sequer entre a plebe do partido. Náo havia, então, a prática de realizar-se uma reunião para que um comitê, de membros locais de um determinado partido, pudesse designar o candidato desse partido (caucus) ${ }^{*}$ que presidiria as comissóes ou seria recrutado para elas. Dificilmente os assuntos tratados por essas comissóes seriam triviais, uma vez que, elas influenciavam virtualmente a legislaçáo que estivesse dentro de sua jurisdiçáo. Portanto, os líderes de partidos, não dispondo de muita força, precisavam negociar e barganhar com os presidentes das comissóes. Além disso, a importância da Coalizăo Conservadora, que abrangia Republicanos e a maioria Democrata conservadora do sul, tornou-se proeminente nas décadas de 50 e 60 . Na maior parte do tempo deteve o poder central, particularmente na Câmara dos Deputados.

\section{A burocracia}

Retornando a esse período de aproximadamente quatro décadas atrás, a burocracia, ou pelo menos, se for tomado como referência apenas aqueles seus elementos que se ocupam da previdência social estatal, foi em grande parte criada pelo New Deal. A carreira de maior categoria no serviço público refletia, especialmente, as circunstâncias políticas em que se deu o crescimento do poder executivo. Os funcionários públicos mais importantés inclinavam-se a apoiar o aumento das atribuiçóes do Estado (nada muito incomum para funcionários públicos $\mathrm{em}$ geral) e a racionalizaçăo do estado de bem-estar social (welfure state), através de sua nacionalizaçáo e universalizaçáo. $\mathrm{Na}$ divisáo da estrutura política americana, pode-se dizer que esses funcionários estariam mais próximos dos Democratas que dos Republicanos. Os Republicanos năo tinham muito interesse no crescimento do Estado, além das funçóes de manutenção da defesa e questóes correlatas. Por isso, foi surpreendente a descoberta, em 1970, de que apenas cerca de $17 \%$ dos funcionários públicos mais importantes dos Estados Unidos consideravam-se Repu-

* Nos Estados Unidos o termo caucus geralmente refere-se de escolhas de delegados ds convençōes partidárias feitas secretamente por um grupo dirigente, sem a participaçäo dos demais membros que dela deveriam participar. Pode também, por vezes, ter a significaçáo de bancada, comite, bloco. Nesse caso refere-se a grupos informais que votam em bloco, fora do sistema de comisebes permanentes. Por exemplo: biptonic cancus, como se encontra à p.13. Nos Estados Unidos existem atualmente muitos desses grupos na Cámara dos deputados e podem ter caracteristicas regionais, trnicas, ideológicas etc., como black cancous, neral caucus, tactile coucus etc. (N.T.) 
blicanos (6). Esse número mudou após anos de administração republicana que permaneceu no executivo de forma mais ou menos constante desde essa época. Pode-se dizer, portanto, que os mais qualificados funcionários públicos realmente tendiam, embora de forma pouco significativa, mais para o Partido Republicano do que para o Democrata (7).

\section{Grupos de pressão}

Retornando à estrutura dos grupos de pressáo de $\mathbf{4 0}$ anos atrás, observa-se que mesmo os principais eram, na sua maioria, associaçóes não-relevantes - organizações que são federaçóes compostas por membros sem importância. Eles refletiam também interesses funcionais tradicionais, como negócios, agricultura, trabalho etc. Abrangiam grupos como a Câmara de Comércio Americana (U.S. Chamber of Commerce), Associação Nacional de Industriais (National Association of Manufacturers ), Confederação do Sindicato dos Trabalhadores ( $A F L-C I O$ ), formada em 1955, a Organizaçáo Rural Americana (American Farm Bureau), entre outras organizaçōes do tipo. É importante notar que uma das principais mudanças, nesse período, foi a ampla expansão, tanto em quantidade como em espécie, dos grupos de pressão. Além de numerosos, em 1993 o universo desses grupos é bem diferente daquele de 1953 (8). Associaçóes pouco significativas e grupos funcionais não mais dominam essa área. Atualmente, o número de organizaçōes nãolucrativas e de defesa de causas (geralmente de natureza ideológica) têm aumentado vertiginosamente.

\section{Partidos políticos}

Observando-se a natureza e a extensão das diferenças entre os partidos políticos, verifica-se que as tendências fundamentais eram, no passado, relativamente menos intensas, comparadas às de hoje. Embora, nos anos $\mathbf{5 0}$ tenha prevalecido uma noçáo maior de que havia consenso na política americana, na verdade, sempre houve diferenças mais significativas entre os dois partidos principais do que observadores externos (e freqüentemente internos) suspeitaram.

Naturalmente, em algumas questōes, os partidos estavam consistentemente divididos, como no caso relativo à natureza do estado de bem-estar e, até mesmo, no referente à natureza do que se poderia chamar de desenvolvimento do Estado. Os Democratas, sempre mais favoráveis a usar o governo para universalizar e nacionalizar o sistema do bem-estar social e promover, através do Estado, as forças do desenvolvimento econômico. Havia, também, diferenças constantes entre os partidos quando se tratava dos interesses de operários contra empresários e, 
ironicamente, com relação a livre mercado versus protecionismo. A palavra ironicamente está aqui sendo usada intencionalmente por, naquela época, os Democratas representarem o partido do livre comércio, posiçáo que historicamente sempre mantiveram durante o século XIX, enquanto cabia aos Republicanos, de alguma forma, ser o partido a favor do protecionismo. Eisenhower preocupou-se em afastar o partido Republicano do protecionismo e do isolacionismo. É evidente que esse alinhamento sugere algo mais profundo. Principalmente porque, nos anos 50, os Estados Unidos ocupavam na economia mundial, posição mais dominante do que hoje. Conseqüentemente, os sindicatos dos trabalhadores concluíram que, para eles, era mais interessante haver um sistema de livre comércio mundial maior, mesmo porque, há quatro décadas, esse mercado seria inevitavelmente dominado pela economia americana.

Naquela época, os Republicanos ainda reivindicavam o voto negro e tinham esperanças, ao menos durante o governo Eisenhower, de obter uma contrapartida moderada no sul com relaçáo aos brancos segregacionistas dos partidos estaduais Democráticos então existentes. A imagem de que ainda compunham o partido de Abraham Lincoln continuava sendo relevante para os Republicanos. $O$ partido Republicano, $o$ mais novo dos dois principais partidos políticos dos Estados Unidos, foi criado em 1856 como um partido anti-escravagista e na sua segunda disputa eleitoral, em 1860, elegeu Lincoln presidente. Nos anos 50 os republicanos apoiavam os direitos civis para os negros, na verdade, com maior consistência do que os Democratas, devido à imensa ala sulista que estes precisavam satisfazer. Somado a tudo isso, havia ainda a influência exercida, no interior do partido Democrático, pelos estados limítrofes (borders states), nos quais a segregaçáo persistia fortemente, embora menos rígida que nos antigos estados confederados.

As diferenças regionais eram, em geral, maiores em todos os aspectos relacionados à política, à economia, à cultura e à culinária, do que as de hoje. O sul era muito menos desenvolvido economicamente e menos urbanizado do que o norte. Politicamente, a questáo racial caracterizou o sul de maneira peculiar. A porcentagem da população negra nos estados sulinos era, de longe, muito mais elevada que o total da populaçáo do norte. Os Democratas podiam quase sempre contar com o sul e com os estados limítrofes nas eleiçóes nacionais. Por vezes, poderiam mesmo conquistar os estados montanhosos ( mountain states), região de pouca densidade demográfica das montanhas rochosas, e o deserto a sudoeste.

Os Republicanos, por sua vez, contavam com os votos dos estados da Nova Inglaterra, ao nordeste, com os estados fortemente agrícolas ou 
estados da planície (plain states) do meio oeste e, até certo ponto, com os da costa oeste. As grandes disputas realmente ocorriam nos estados com grandes metrópoles como New York e outras cidades pouco menores como Philadelphia e Pittsburgh no estado de Pennsylvania, Chicago, em Illinois, Detroit, em Michigan ou Los Angeles e San Francisco na Califórnia. Era comum haver grandes disputas políticas por ocasiáo das eleiçóes gerais para governo desses estados, para o Senado e para a presidência. Ao norte, as grandes cidades eram bastióes das forças do partido Democrático, enquanto as menores eram os pilares que sustentavam os Republicanos. Particularmente no sudoeste, com o aparecimento e o crescimento dos subúrbios, surgia e se desenvolvia um padrão de alguma forma diferente. Este fenômeno ocorria, também, em alguns dos estados do sul, onde o Republicanismo tendia a concentrar-se especialmente nas cidades (agora nos subúrbios). À época, a base do partido democrático segragacionista no sul encontrava-se na zona rural e nas pequenas cidades do sul e sudoeste.

O pleito de 1952, que elegeu Eisenhower o primeiro presidente republicano em 20 anos, quebra a coalizão nacional dos Democratas. Em 1948, os sulistas segregacionistas abandonaram a Convençáo Nacional do Partido Democrático, formando o partido dos Direitos dos Estados (States Rights) que venceu em quatro estados do sul, nas eleiçóes daquele ano. $O$ chamado solid south* nesse momento se desintegrava. Em 1952 alguns dos estados sulinos apoiavam Eisenhower Virginia, Florida e Texas. Atualmente, nas eleiçóes presidenciais, esses estados são quase totalmente pró-Republicanos. Em 1964, o alinhamento tradicional romper-se-ia completamente nas eleiçóes nacionais, alterando regionalmente o quadro político partidário. De maneira geral, nas eleiçóes presidenciais, o mapa eleitoral apresentava situaçáo de expansão do voto republicano enquanto o do democrata aparecia diminuído.

\section{Problemas}

Como já discutido, até então, quando se realiza uma comparaçáo entre o presente e o que ocorria há quarenta anos, nota-se a existência de uma gama moderada de diferenças entre os partidos. Pode-se afirmar que, em parte, isso se deveu aos reduzidos problemas existentes na agenda política daquela época em contraste com a atual. Questóes como o aborto, entre outras, definidas como problemas de ordem cultural ou de estilo de vida, não eram visíveis, principalmente por serem temas ina-

* Entenda-se por solid south os estados do sul que tradicional e compactamente apoiavam o Partido Democrata. (N.T.) 
bordáveis. Na história política americana, por vezes, o conflito entre os valores tradicional e secular emerge, como importante e destacada fonte de clivagem política. Embora, certamente, nos anos 50, esse fenômeno houvesse diminuído, em parte, ainda é possível explicá-lo, porque a sociedade americana, nesse período, era muito mais homogênea culturalmente do que nos dias atuais. Portanto, há quarenta anos, os valores convencionais - ou ao menos um conjunto diferente desses valores eram mais dominantes do que atualmente. Um grande número de direitos ainda restou para ser reivindicado nas décadas subseqüientes.

Por mais incrível que possa parecer, o crime só se torna um problema em 1968. A rigor, o crime não representava, até então, assunto relevante. Mesmo porque, o governo federal náo tem, com relaçáo a essa questáo, papel muito importante a desempenhar, desde que, sequer, há regras bem-definidas. Entretanto, é um ponto extremamente importante, sobretudo, pelo fato de possuir conotação com fins simbólicos, uma vez que é inconcebível ser favorável ao crime. Na eleição de 1968, o crime foi utilizado como tema de campanha por dois políticos oponentes: George Wallace, o governador segregacionista do Alabama, concorrendo como independente e Richard Nixon, indicado pelo Partido Republicano. Wallace, o candidato dos segregracionistas do sul, porém com implicaçóes nacionais, combinava apelos populistas com tendências autoritárias. Ambos tentaram capitalizar os distúrbios raciais que eclodiram nas cidades americanas entre 1964 e 1968, durante a administração do democrata Lyndon Johnson - um governo considerado favorável aos interesses dos negros. É a partir dessa época que a questão racial começa a aparecer com muita consistência na política americana, transformando-se, paulatinamente, em um tema nacional. Nesse processo, torna-se, cada vez mais, uma questão partidária (9).

O aparecimento de exigências, por parte de setores da sociedade que antes não participavam do sistema político, dá nova magnitude à complexidade do cenário político e das políticas públicas americanas. Como exemplo, pode-se citar os grupos feministas que começaram a surgir na política americana no final dos anos 60 e princípio dos 70 , pois, em 1953, tais grupos não possuíam qualquer força política. Grupos de homossexuais que começaram a ser uma parte importante na coalizão pró Clinton em 1992, principalmente como força financeira, estavam literalmente fora de cena em 1953. Nessa época, a sociedade, simplesmente, possuía mais tabus e valores convencionais. $O$ conjunto dominante de valores era indicador de uma situação que sugeria quão pouco provável seria que certas questóes figurassem na agenda política. Essa circunstância permitia que grupos minoritários permanecessem à margem da sociedade e suas aspiraçōes certamente ignoradas, a não ser 
como objeto de desaprovação. Indubitavelmente, em 1953, poucos desses grupos, ao contrário do que ocorre em 1993, encontraram eco ou condiçốes de se tornarem politicamente mobilizáveis. Há quarenta anos atrás, com exceçáo do pânico do perigo vermelho e das táticas de caça aos comunistas do Senador Joseph McCarthy e alguns de seus colegas, a política era uma atividade muito mais tranqüila com um complexo menos denso de organizações ativistas. Havia, com relaçáo aos nossos dias, menores diferenças partidárias e estreita margem de questōes a serem contestadas. Tudo isso refletia o pequeno conjunto de reivindicaçóes que poderia ser filtrado pelo processo político nessa época. Existia menos conflito porque náo havia tantos participantes $e$ a diferença entre estes era menor.

Além disso, o estilo de liderança do Presidente Eisenhower era relativamente não partidário e não confrontante. Com freqüência, consultava os líderes do Partido Democrata no Congresso, e buscava ajuda junto a eles, sobretudo porque haviam readquirido a maioria após as eleiçóes de 1954.

Enquanto a economia americana estava crescendo e a guerra fria era o tema central da vida política, também se desenvolvia a sensação de que nenhum problema seria tão grande ou de impossível soluçăo. Essa atitude, obviamente, era ingênua; contudo, havia entáo, nitidamente, um sentimento de confiança na capacidade de o governo agir corretamente (10).

\section{Quarenta anos de transformação}

A pergunta que agora se coloca é: quais foram as transformaçóes que ocorreram durante esse período? $O$ primeiro ponto a ser tratado será o que diz respeito ao grande público e aos alinhamentos políticos, prosseguindo com as instituiçóes e terminando com os problemas das políticas públicas.

\section{Transformações no grande público e no alinhamento político}

Em primeiro lugar, como observado anteriormente, há agora uma taxa menor de participaçáo eleitoral comparada ao período de 1952 a 1960, apesar da ligeira ascensão ocorrida na eleição de 1992. Em parte, esse crescimento poderia ser atribuído à presença de um terceiro candidato, Ross Perot. Número considerável de análises tem sido realizado com relação ao desinteresse pela participaçáo política através do processo eleitoral, não se chegando, porém, a qualquer conclusáo que eviden- 
ciasse o fenômeno. A diminuição da participação pelo voto praticamente vem ocorrendo em todos os grupos da sociedade americana. A participaçáo eleitoral já foi descrita pelo político socialista S. M. Lipset como um meio democrático de expressar a luta de classes (11). Realmente, a votação está menos subordinada à influência da identificação com a classe do que outras formas de participaçáo política. Ironicamente, essas outras formas de participação política, que estão em crescimento, manifestam-se através dos mais sofisticados espaços de mobilizaçáo de grupos de pressão, realizando petiçóes e contatos com líderes políticos etc. Ao mesmo tempo, é importante notar dois fatos:

- a queda da participação pelo voto é relativamente uniforme e portanto um grande mistério;

- os que não votam não possuem preferências diferentes dos que votam (12).

Em segundo lugar, houve maior democratizaçáo neste período de quarenta anos em meio a crescente diversificaçáo da sociedade americana. Especialmente, após 1965, o acesso dos negros às urnas aumentou maciçamente devido às proteçôes federais acordadas pelo direito de voto originadas do Ato de Direitos do Voto (Voting Rights Act). Considerando as enormes diferenças de status sócio-econômico, a participação dos negros nas eleiçóes, em níveis equivalentes, é, na verdade, maior do que a dos brancos (13).

A população com o mais alto índice de crescimento nos Estados Unidos é a de língua espanhola. Essa populaçăo apresenta, também, grande diversificação e é originária de diferentes lugares. Os cubanos, na Flórida, que representam o grupo com o mais rápido desenvolvimento, são uma exceção. Esse grupo vem se tornando uma população afluente, composta de profissionais e executivos, com participaçáo política que tende a ser mínima e com forte inclinaçáo para votar no Partido Republicano. É bem provável que a diversidade da populaçáo de língua espanhola nos Estados Unidos, a imigração relativamente recente e a barreira da língua impeçam sua mobilização.

A elite política, também, tornou-se, de alguma forma, mais representativa da sociedade americana do que era em 1953. Naquela época havia dois negros na Câmara dos Deputados e nenhum latino. Havia pouquíssimas mulheres e quase todas exercendo cargos políticos, haviam sucedido a seus maridos, falecidos em exercício. Atualmente, cerca de $70 \%$ da população americana é de descendência européia direta (14), o que significa uma mudança bem dramática ao longo do tempo. Dentre os membros da Câmara dos Deputados, cerca de $10 \%$ 
(38 num total de 435) são afro-americanos, aproximando-se à porcentagem da populaçáo de adultos afro-americanos. Aproximadamente $\mathbf{9 \%}$ dos membros sáo mulheres, índice ainda baixo, mas que aumentou maciçamente ao longo dos anos. Há atualmente um comitê de membros hispânicos na Câmara (caucus) moderadamente significativo, cerca de 4\% (18 deputados). A maior parte deles é de ascendência mexicana. Muitos dos prefeitos das grandes cidades foram ou ainda são membros de grupos minoritários. Muitas das grandes cidades americanas tiveram, recentemente, ou ainda têm, prefeitos negros e, algumas cidades, hispânicos. O governador (1990) de um estado razoavelmente grande, ironicamente o tăo conservador estado de Virginia, é afro-americano.

Em terceiro lugar, o Ato dos Direitos Civis (Cipil Rights Act) de 1964 atingiu o status de um importante divisor de águas por repartir os votos dos candidatos indicados para concorrer à presidência naquele ano entre os Partidos Democrático e Republicano, ou seja entre o Presidente Johnson e o Senador Goldwater. Neste caso específico, até um determinado momento, houve certo tipo de consenso com relaçáo à defesa dos direitos Civis, mas então houve um rompimento. Lindon Johnson comprometeu os Democratas com a revoluçáo dos Direitos Civis e acreditava ter tido a honra de, ao agir assim, ter custado aos Democratas a sua posiçáo política majoritária. Tal especulaçáo provouse estar correta. Barry Goldwater, indicado pelos Republicanos, opôs-se a lei dos Direitos Civis de 1964 e às suas cláusulas de ajustamento igualitário. Essencialmente, esse rompimento deu início a uma nova fase eleitoral na política americana. Os brancos sulistas tornaram-se progressivamente Republicanos. Da mesma forma, os estados do sul que vinham atraindo a migraçáo de outras partes do país, principalmente os aposentados, tornaram-se cada vez mais Republicanos. Por outro lado, aumentou enormemente o número de negros Democratas.

A sociologia do alinhamento dos partidos apresentou uma tal troca de posiçóes podendo-se afirmar que realmente foram iniciadas algumas transformaçóes. Pode-se analisar, por exemplo, quatro acontecimentos específicos: Primeiro, as bases eleitorais dos partidos tornaramse internamente menos contraditórias e mais coerentes. Segundo, esse fato ocorria com muito mais força no âmbito da elite, produzindo um grau relativamente elevado de partidarismo e coesão partidária do que existe hoje (15). Os Republicanos estavam se tornando, cada vez mais, conservadores e os Democratas mais liberais. Paradoxalmente, entretanto, os partidos iam perdendo a identidade com o povo. No que concerne à população, havia menos identificação com os partidos políticos. Uma porcentagem menor da populaçáo se considerava Republicana ou Democrata e havia menores conseqüências, com relação ao comportamen- 
to, no que se referia à identificação com o partido, do que anteriormente (16). Não há, proporcionalmente, apenas menor número de Democratas e Republicanos no eleitorado, mas, também, a probabilidade de deserçăo eleitoral de sua identificação partidária manifesta é maior. Portanto, do ponto de vista do grande público, o partido parece ter menor significação na mente do eleitorado individual, uma conclusáo peculiar, uma vez que se constatou a existência de maior homogeneidade dentre os seus seguidores.

Como última conseqüência, há enorme incoerência entre os resultados das eleiçóes presidenciais e congressionais e os seus eleitores. Ao cabo dessas eleições, o produto obtido, na maioria das vezes, era um governo dividido. Um eleitorado desconexo ajuda a criar um resultado político desconexo. Já se tornou uma constante presidentes Republicanos se confrontarem com Congressos Democratas. Ao contrário do que ocorre na atualidade, em 1953 não era comum os Republicanos elegerem o presidente. Com relação ao Congresso, o eleitorado está relativamente mais interessado na distribuição de benefícios, ou, para usar o coloquialismo americano, bringing home the bacon (levar vantagem em tudo). Nesse ponto, os Democratas parecem ter se saído bem melhor que os Republicanos, em parte porque acreditam que deva existir mais vantagens que possam ser oferecidas pelo governo. Esse processo de desconexáo eleitoral representa um forte incentivo aos membros do Congresso para cuidar melhor do seu eleitorado local. Dessa forma, podem isolar-se de questóes e imagens que influenciam eleiçóes presidenciais.

Desde 1974, o grande paradoxo existente resulta do fato de que os membros do Congresso têm se tornado ideologicamente mais coesos dentro do mesmo partido. Entretanto, essa maior coesão de mentes confronta-se com a desconexáo dos processos. A desconexáo significa que os membros do Congresso, antes de mais nada, precisam assegurar sua invulnerabilidade eleitoral. Um presidente (especialmente um Democrata) pode precisar do Congresso, mas os membros do Congresso (principalmente um Democrata) não precisam necessariamente de um Presidente.

Ao longo do tempo, tem havido uma mudança no eleitorado, segundo a qual uma coalizáo naturalmente majoritária, de Democratas passou a ser Republicana e uma deslegitimação do rótulo liberal tal como é usado de forma específica no contexto americano (hoje significando muito mais uma combinaçáo de social-democrata, verde, $\mathrm{e}$ ideologias libertárias, do que sua definiçăo clássica de livre-arbítrio). Liberais e liberalismos nos Estados Unidos tornaram-se identificados com 
causas impopulares, por exemplo, o transporte de ônibus escolar obrigatório, de 1970, e éditos que essencialmente vinham de funcionários náo-eleitos, em geral de órgáos burocráticos ou juízes. Liberalismo também identifica-se com mudanças sociais e culturais consideradas impopulares como uma ameaça aos valores tradicionais. Identifica-se também com as reivindicaçóes proferidas por novos grupos minoritários, principalmente os de negros e de feministas, que estão construindo o seu caminho em direção ao sistema político; $\mathrm{e}$, ainda, com a concessão dos direitos de bem-estar para as pessoas de baixa renda, as quais na mentalidade popular, são os negros pobres.

Entretanto, o desencanto popular não era, realmente, contra o estado de bem-estar em suas manifestaçóes específicas. A opinião dominante considerava válidas as vantagens concedidas à classe média, tais como previdência social e seguro saúde (pensão e programas de saúde à população idosa), provavelmente porque esses direitos foram adquiridos como parte do esquema do seguro social. O significado das palavras é muito importante nesta discussão. No sentido americano bem-estar (welfare) significa o que os ingleses chamam (dole)*. Previdência social, outro termo usado para definir bem-estar social, significa claramente um tipo de esquema de seguro para a classe média. A referência ao sistema de seguro social, quando contrastado com o subsídio pago pelo governo, é o povo pagar sua contribuição para o sistema durante os anos que trabalha e, portanto, merecer um retorno. Porque a sociedade tende a dizer uma coisa acerca das despesas com o bem-estar, enquanto é outra a sua significação, os Republicanos encontram-se mais limitados, pela opinião pública, em reduzir o estado de bem-estar, do que a retórica popular sugere.

\section{Mudanças nas instituiçōes}

$\mathrm{Na}$ década de 70, a começar pelo Congresso, ocorreram importantes mudanças. Algumas delas, como reaçáo direta ao governo de Richard Nixon. Outras foram essencialmente conseqüências de causas mais naturais. No interior da sociedade americana e de suas instituiçóes houve uma tendência crescente à democratizaçáo e um respeito menor com relação às organizaçóes de líderes. Em nenhum outro lugar essas diferenças se manifestaram com maior evidência do que dentro do próprio Congresso. No início dos anos 70 , as subcomissóes e as direçóes destas tornaram-se muito mais importantes do que haviam sido no pas-

* Dole para os ingleses significa salário desemprego ou outra forma de subsídio pago pelo governo. (N.T.) 
sado. Anteriormente, a presidência das principais comissóes permanentes era muito poderosa. Uma das formas de destruir o poder das comissōes e de seus presidentes, em geral autocráticos, era distribuir mais as atividades para as subcomissões e muni-las de auxiliares independentes.

Em meados da década de 70, ao menos na Câmara dos Deputados, os líderes e os caucus dos partidos ganharam muita importância. Assim, nesse caso, verificamos, mais uma vez, haver duas tendências aparentemente opostas: o crescimento do individualismo e o crescimento da fragmentaçăo. As subcomissóes e suas presidências tornaram-se mais importantes, porém, o mesmo aconteceu com os partidos. Os Democratas, por exemplo, em meados dos anos 70 , recorreram a um expediente usado no século XIX e início do XX, ou seja, o caucus do partido. A partir de então, os presidentes das comissōes e até mesmo os das subcomissóes precisavam se submeter aos caucus do partido e serem eleitos por eles. A regra anterior baseava-se apenas no respeito à antigüidade. Um representante ganhava automaticamente um posto mais elevado à medida em que aumentava o seu tempo de trabalho. Normalmente, a antigüidade ainda prevalece. Entretanto, se o presidente foi inconsistente com a linha do partido ou considerado alguém com dificuldades para se manter no posto, a presidência poderá, então, ser ocupada segundo o julgamento do caucus do partido. Dessa forma, a influência e o papel dos caucus partidários aumenta. $E$, uma vez que o caucus do partido tome uma posição, espera-se que os seus membros apóiem as decisōes tomadas. Apesar disso, não se pode controlar completamente os seus membros quando estes possuem fortes motivos (tendência do eleitorado) que os desviem do caminho de seu partido. Porém, em seu conjunto, os interesses do partido e do eleitorado tendem a se consolidar ao invés de contraporem-se um ao outro. Ao longo da década de 80, as divisóes dos partidos tornaram-se muito fortes no Congresso, principalmente na Câmara dos Deputados e adquiriram maior vigor durante o governo Reagan. Como se pode observar, por exemplo, no caso da aprovaçáo do projeto orçamentário quando, em ambas as Câmaras, houve oposição unânime por parte dos Republicanos às propostas administrativas de Clinton. $O$ fato de essa votação ter sido tão apertada, está relacionado à unanimidade da oposição Republicana e porque na verdade, apenas um pequeno número de Democratas desertou. Os Democratas votaram a favor da proposta de Clinton, num percentual entre 85 e $90 \%$, mas o fato de nenhum Republicano ter passado para o outro lado foi o que tornou a votaçáo tão apertada. A confrontação entre partidos, partidarismo e coesão partidária tornara-se mais forte em nível nacional. Ainda assim, comportamentos enfatizando o individualismo político também permanecem vigorosos nos Estados Unidos. Como conseqüência, os membros abandonam o programa dos 
seus partidos quando consideram que sua adesão poderá torná-los vulneráveis.

Nos anos 70, o Congresso fortaleceu sua capacidade de controlar as açóes do executivo e de se envolver com análises sobre as políticas públicas, embora quase sempre também na policy making. Houve mais audiências, mais condução e controle do comportamento do executivo e considerável desconfiança com relaçáo a este comparado aos anos $\mathbf{5 0}$ ou mesmo aos 60. O desenvolvimento dessas capacidades do Congresso foi desencadeado em razão de algumas atitudes altamente arbitrárias por parte da Casa Branca, na época de Nixon, com relaçáo ao Congresso. Essa atitude de desconfiança tendeu a persistir ainda quando o mesmo partido detinha o poder em ambos os setores do governo. E prosseguiu, mesmo quando o Presidente Carter estava na Casa Branca e o Partido Democrático tinha a maioria no Congresso.

Resumindo, há maior centralizaçăo das lideranças dos partidos no Congresso. Atualmente, os líderes dos partidos têm maior poder do que há quatro décadas. São pessoas muito mais influentes e os próprios partidos estáo ideologicamente mais coesos. Ao mesmo tempo, porém, há maior fragmentação no Congresso. As subcomissóes se expandiram e estão mais influentes. Os projetos de leis podem ter múltiplas implicações e, por isso, partes desses projetos são destinadas às diferentes comissóes e subcomissóes. Há mais atores no processo de policy making e, inevitavelmente, mais confusão. Os modestos esforços em direção à centralização são destinados a moderar a confusão.

A Câmara dos Deputados é a mais organizada por partido e menos sujeita às idiossincrasias individuais de seus representantes. Em geral, é também o corpo mais sensível às suas maiorias. O Senado, além de apresentar menor sensibilidade às suas maiorias, atende mais às demandas de seus membros individualmente. Suas regras permitem emendas não-relevantes e debates infindáveis (conhecidos como obstrucionistas). O obstrucionismo (debate contínuo que impede a açáo legislativa) vem sendo utilizado cada vez mais, como recurso do partido minoritário no Senado, para forçat uma reação da maioria. O Senado, planejado pelos construtores da Naçáo para ser o corpo sensível à opinião da minoria no interior da Câmara, está hoje freqüientemente sob controle da minoria, o que só não ocorre, quando o partido majoritário detenha $60 \%$ ou mais dos votos - porcentagem necessária para se invocar a moção que ponha fim ao debate. Os Republicanos, por exemplo, nos primeiros meses da administraçáo Clinton, obstruíram quatro projetos de lei consecutivamente, amarrando de tal forma o Senado que este não conseguia dar prosseguimento a nada. A estratégia, claramente, visava 
forçar os Democratas a negociar. Em outras palavras, um recurso que raramente era utilizado há quarenta anos (o que foi feito, a maioria das vezes, pelos senadores sulistas contra a legislação dos Direitos Civis) hoje é utilizado como rotina. Seu uso crescente reflete o enorme aumento da força partidária. Além disso há, no Congresso, utilização maior de um mecanismo de pressáo - o exercício de privilégio pessoal usado por um senador - que pode entravar o Senado por longo período. As pressóes, com freqüência, são colocadas quando das indicações presidenciais aos cargos executivos complicando, portanto, os processos de nomeaçáo e dificultando o andamento das audiências com os indivíduos indicados. Um pequeno número pode criar um alto grau de paralisação.

Voltando a questão dos partidos, é importante enfatizar, mais uma vez, que 1964 e 1965 foram os momentos máximos de divisão da massa e de muitas oportunidades para os Republicanos se organizarem no sul, aliás, o que fizeram. O envolvimento dos Estados Unidos no Vietnã, a disputa que se deu no interior do Partido Democrático, em 1968, em torno do lançamento do vice-presidente em exercício (Hubert Humphrey) como candidato à presidência, por indicaçáo dos senadores Eugene MacCarthy, Robert Kennedy e Georges McGovern e a infeliz candidatura de McGovern, em 1972, representaram um conjunto importante de mudanças políticas da elite. Proponentes da guerra fria, freqüentemente conduzidos pelos neo-conservadores pertencentes à antiga coalizão do Neñ Deal, gravitavam cada vez mais em direçáo ao Partido Republicano. Muitos deles tiveram papel de destaque na administraçáo Reagan.

Os ativistas e o dinheiro tornaram-se especialmente importantes. Isto se deve, em parte, à função que a investida da televisão adquiriu e ao colapso das máquinas partidárias locais. As eleiçóes presidenciais são essencialmente nacionalizadas. As comissóes nacionais dos partidos doam, cada vez mais, dinheiro às disputas ao Senado e à Câmara $e$, portanto, as organizaçóes centrais do partido começam a desempenhar papel mais destacado no fornecimento de apoio aos candidatos. Especialmente os Democratas tornaram-se dependentes, ainda, dos recursos dos grupos de pressão canalizados pelas Comissóes de Ação Política (Political Action Committees - conhecidas pela sigla PACs). Do ponto de vista das contribuiçóes financeiras, os Democratas receberam boa parte de seu apoio da indústria de lazer e da elite artística e cultural com tendência a se concentrar em New Yoṛk e Los Angeles. Outra grande parte do eleitorado encontra-se nos sindicatos de trabalhadores. Nos Estados Unidos, entretanto, esses tiveram sua importância política atrofiada, durante esse período, à medida que se tornaram economicamente 
mais fracos. Os Republicanos extraíram seu considerável apoio financeiro dos lucros das empresas e de numerosos contribuintes individuais.

Dentre os ativistas dos partidos, os Democratas são muito liberais, em especial no que se refere aos valores culturais; os Republicanos, ao contrário, são muito conservadores e tendem a ser especialmente tradicionais quanto aos valores culturais. Esses ativistas conservadores, que abasteceram o Partido Republicano em 1992, podem ter ajudado Bush a perder a eleiçáo devido tanto à questáo do direito ao aborto quanto ao crescimento do fundamentalismo religioso entre eles. Alguns eleitores comuns do Partido Republicano com perfis de educaçáo superior e alta renda, desertaram e votaram no candidato Democrata. Provavelmente se sentiram fora de sintonia com os ativistas religiosos de direita, os quais, por sua vez, consideraram o Partido Republicano como um meio conveniente de pressão para ativar a sua agenda. Um problema básico que se coloca é saber se os partidos que se distanciam ideologicamente e se opóem, com mais freqüência e consistência, um ao outro em relação à questóes de pouca importância para o grande público, ajudam a criar tanto impasses quanto desconfianças no sistema político. Afinal, um dos pontos observados nesse espaço de tempo foi o declínio da confiança que o público tem no governo. Dentre outras tendências, certamente, tem sido o aumento do partidarismo e a expansão do conjunto de problemas que atualmente sáo objeto dos conflitos partidários.

O aumento das políticas públicas, especialmente as dos anos 60 , e a ascensão de recentes e claras reivindicações produziram tanto a expansáo da burocracia, quanto a dos grupos de pressão e, possivelmente, como conseqüência, uma diminuição do excedente social. Expansão burocrática significa novos programas, novos compromissos de gastos, novos departamentos públicos. Muitos desses fatos ocorreram nos anos 60 , durante os governos dos presidentes Johnson e Nixon. Os programas em si tendem a fomentar o aumento dos grupos de pressáo. Tais programas, desenvolvidos a partir de meados de 1960 até a metade de 1980, ajudaram a gerar, nesse cenário, um imenso crescimento do número e de tipos de grupos de pressão (17). Muitos desses grupos recorrem a técnicas sofisticadas de lobby. Procuram concentrar suas pressóes, menos nos próprios membros do Congresso e mais exercendo-as fortemente sobre seus alvos, através do uso de técnicas de propaganda na mass media, em áreas de residência dos respectivos membros. Essa prática ajuda a gerar o envio de correspondência do público a esses membros (18).

Do ponto de vista presidencial, o problema é conseguir controlar o confuso processo político. Uma das soluçóes utilizadas pelos presiden- 
tes tem sido o esforço de aumentar a centralizaçáo do executivo e buscar maior controle da Casa Branca sobre os órgáos administrativos (19). Esse esforço, por sua vez, geralmente provoca conflitos no Congresso, que se inclina a apoiar programas de despesas e gastos com impostos (incentivos fiscais a vários interesses) (20). $\mathrm{Na}$ área do executivo, a disputa que ajuda a gerar esta tensāo entre o executivo e o Congresso é aquela que se dá entre as demandas dos órgãos que administram os programas e estáo sempre buscando os mesmos ou mais recursos para os seus programas específicos, de um lado, e, de outro, as agências financiadoras, em especial o Departamento de Administraçáo do Orçamento (Office of Management and Budget - OMB), que reparte e encaminha as verbas dispostas pelos fundos em direçáo às agências executoras. O OMB reporta-se diretamente ao presidente. A legislatura, tipicamente, é mais solidária com as agências executoras e, o presidente, mais solidário com as agências financiadoras e controladoras. Tal fato oscila, até certo ponto, de acordo com o presidente em exercício e muito mais com relação ao partido por ele representado. Os presidentes Democratas tendem menos à centralização da Casa Branca do que os Republicanos. A principal razão disso advém das prioridades estabelecidas pelos presidentes Republicanos que estáo voltadas mais exclusivamente ao controle das finanças do que estão as dos Democratas. Essa atitude dos Democratas os coloca em disputa com as agências executoras e seus patronos no Congresso.

\section{Transformações nos problemas}

Indubitavelmente, em alguns aspectos, os Estados Unidos são hoje diferentes do modo como se apresentavam quarenta anos atrás. Em primeiro lugar, o conjunto de problemas públicos enfrentado pelo país mudou consideravelmente nas últimas quatro décadas. A sociedade está muito diversificada e mais democrática, assim como suas instituiçóes internas. Os Estados Unidos mantiveram à distância seu maior desafio observado nessa época, ou seja, sua disputa com a União Soviética, a guerra fria. Apesar desse triunfo, houve desgaste da confiança no governo, crescimento elevado de crimes de desintegraçáo social, baixo nível educacional alcançado por grande parte da populaçáo, alto índice de nascimentos ilegítimos e estagnação da renda (os salários não aumentaram em vinte anos). Houve, também, mudanças no mercado de trabalho que propiciaram a diminuição da confiança entre empregados e patróes, enfraqueceram os sindicatos de trabalhadores, aumentaram os temores de instabilidade de emprego e aprofundaram a diferença de renda entre aqueles que possuem e os que não possuem educação de nível superior. Além disso, novos problemas fiscais têm sido gerados desde os primór- 
dios da década de 80 em razão da emergência de enorme déficit estrutural.

Em suma, o excedente social diminuiu e tem havido substituiçăo nos cargos de altos salários no setor industrial em direçáo aos empregos de menor salário no setor de serviços. Talvez seja essa a causa da impressionante eficiência do setor industrial norte-americano. A taxa de desemprego e o nível salarial nos Estados Unidos sáo inferiores aos das economias européias. O nível salarial na Alemanha, por exemplo, é aproximadamente $50 \%$, em média, mais alto do que nos Estados Unidos. Náo é surpreendente que as companhias alemãs estejam começando a se instalar nos Estados Unidos. No Japão, o nível salarial, é cerca de $25 \%$ mais alto e, do mesmo modo, não causa surpresa o fato de muitas companhias japonesas terem se instalado nos Estados Unidos, onde se encontram em posiçăo de adquirir vantagens no acesso ao vasto mercado americano.

Será que o governo poderá enfrentar esses problemas? Mais importante ainda, poderá a sociedade enfrentá-los? Nos anos 80 , a administração Reagan respondeu a essas questóes, basicamente, prometendo a todos almoço gratuito (free lunch) e menores impostos, sem reduzir benefícios. Isso não afetou os direitos da classe média, embora, dificilmente possa-se acusá-lo de não ter tentado. De fato, quando, a administração Reagan, buscou ajustar o custo da previdéncia social do elevado nível de vida, para baixo, sua proposta foi rejeitada por 99 a 0 votos no Senado. Esse resultado passou ao governo uma evidente mensagem: que não deveria defrontar-se abertamente com os direitos da classe média. Pelo contrário, essa administraçáo, procurou lidar com os problemas da previdência social de duas geraçóes, mudando as regras para a aposentadoria e aumentando os impostos nas folhas de pagamento. Para tal fim, ajudou na formação de uma comissão bipartidária para estudar o amplo alcance do seguro do programa de benefícios da previdência social. Obviamente, essa política fragmentou alguns programas auxiliares que recentemente haviam aberto caminho dentro do sistema de previdência social. A medida também cortou os programas de rendimentos ou de apoio às vantagens sociais (pré-natal, assistência médica na primeira infância, merenda escolar pela manhã etc.) às pessoas de baixa renda. $\mathrm{Na}$ verdade, isso significou enfraquecer o apoio ao trabalhador pobre.

Ao indexar os impostos de renda, como parte do plano de tributação de Reagan em 1981, os políticos náo puderam mais esconder os aumentos de impostos, como habitualmente faziam, simplesmente em virtude da inflaçáo embutida no aumento das receitas provenientes de impostos. Entretanto, após 1981, os políticos precisavam votar aberta- 
mente a favor do aumento de impostos, o que fez com que, atualmente, seja muito mais penoso elevar as taxaçóes. Além disso, os custos políticos associados a tal atitude são muito maiores. Como conseqüência, na ausência de corte de gastos maciços com relação aos direitos sociais universais, os quais representam a grande soma dos gastos federais, o déficit estrutural continuará a crescer, a não ser que se chegue a um acordo quanto ao meio de se conseguir elevar a receita pública. Por fim, o principal problema é que se não se mantiver os direitos sob controle, os aumentos de impostos podem proporcionar, a curto prazo, somente paliativos relativos.

Apesar da expectativas, o fim da guerra fria não significa, necessariamente, que se possa melhorar a capacidade de se tratar com o déficit. Mesmo se o Departamento de Defesa deixasse de existir amanhã, o déficit poderia apenas ser coberto por menos de um ano. $O$ déficit esperado para o atual ano fiscal representa mais de US\$ 350 bilhóes, enquanto os gastos com a defesa são de aproximadamente US\$ 290 bilhôes.

Mesmo com a recente aceitaçăo do pacote orçamentário de Clinton, em nova versão, o déficit continua sendo um grande problema. Os custos políticos vinculados à adoção desse, até modesto, programa de aumento de impostos e cortes de despesas sáo bastante significativos. $O$ sistema de tributo americano pesa na receita, nos lucros e nos impostos da folha de pagamento, porém é muito baixo nos impostos de consumo. Para uma sociedade cuja função das poupanças está próxima da base das economias de alta renda, pode-se especular que seria bastante lógico aumentar os impostos sobre o consumo, a fim de ajudar a elevar as poupanças. De fato ocorre o inverso: a poupança é taxada, mas o consumo não.

Evidentemente, a redução do déficit não é um objetivo em si. É simplesmente um meio de liberar os potenciais capitais de investimento. Para onde esse capital irá e o que ele proporcionará é uma outra questáo. Os políticos americanos, como os políticos de outros países, apreciam baixos custos, baixos riscos, decisóes de alto rendimento político e é por isso que os cidadãos americanos, como os de outros países, querem almofo gratuito. $O$ fato é que os cidadáos não vêem o que seus sacrifícios financeiros podem render. Reduzir o déficit para evitar taxas de juros altas não faz sentido para o cidadão comum, mesmo se a relaçáo entre as taxas de juros e a lentidáo do crescimento econômico possa ser comprovada. Tudo isso é muito abstrato. Maiores sacrifícios não estão, necessariamente, ligados diretamente ao que os cidadáos tendem a crer que é importante, ou seja, sua segurança econômica e física. 
Pode-se observar que o setor industrial americano tornou-se altamente eficiente. Uma das razóes para tal eficiência é que há poucas pessoas trabalhando nesse setor. Companhias em dificuldade como a IBM, a General Motors e as da indústria de aviaçáo vêm demitindo grande contingente de empregados. Mas, também, companhias lucrativas, como Kodak e Xerox estão dispensando empregados para aumentar suas margens de lucro e assegurar seu futuro (21). O dilema é que boa sauide no setor econômico náo pode mais ser traduzida como boa saúde no mercado de trabalho. Quem sabe como gerar empregos bem remunerados? Sobretudo, quem é capaz de criá-los de tal modo que isso náo impeça sua eficiência? $\mathrm{E}$, será possível treinar pessoas de baixa qualificação para esses empregos? Não há mais, nos Estados Unidos, empregos de altos salários para trabalhadores não especializados. Tal mudança é incrivelmente consistente neste período de quatro décadas. Seus efeitos conduziram ao aumento da insegurança dos empregados, ao mesmo tempo que obstruiu a penetraçáo no mercado de trabalho àqueles não especializados.

Com relaçáo ao seguro saúde, será possível para os Estados Unidos criar um sistema de assistência médica que englobe os seguintes pontos:

- concessão de cobertura universal;

- manutenção ou melhora dos serviços assegurados e sua qualidade;

- diminuiçáo dos custos. Grande parte do lucro excedente das companhias americanas tem sido consumida pelos custos de assistência à saúde, os quais são invisíveis para os trabalhadores. Esses custos representam uma das principais razóes do porquê os salários ficaram estagnados nos últimos 20 anos (22).

A resposta à questão levantada, sobre assistência médica é, claramente, năo. Todos esses objetivos não podem ser alcançados simultaneamente. Algumas pessoas, sob qualquer ponto de vista, sempre verão seus interesses serem adversamente afetados por qualquer que seja a proposta oferecida. No momento, a maioria dos americanos que trabaTha em grandes corporaçóes ou em setores náo-lucrativos tem a proteçáo de algum seguro e o prêmio desse seguro grandemente financiado pelo seu empregador (23). Os empregados tendem a näo considerar o pagamento da cobertura do seu seguro saúde feito pelo empregador como um rendimento, e a maioria provavelmente se opóe a qualquer coisa que aumente seu custo pessoal ou diminua a natureza, a extensăo ou a qualidade da cobertura de seu seguro. É por isso que o pacote de seguro saúde de Clinton está propenso a enfrentar árduo caminho. Há uma 
tendência favorável da maioria quanto à reforma da assistência médica, porém, não com relaçăo a qualquer pacote em particular.

Portanto, o sistema americano, em que se multiplicam as situaçóes de veto e de acesso popular à arena dos poderes políticos, torna as decisóes impopulares extremamente difíceis de serem realizadas. Enquanto muitas dessas decisóes necessitam ser tomadas, nenhuma produzirá qualquer panacéia. Este é o dilema em curso nos Estados Unidos, em um tempo, em que o governo é visto pelo público mais como parte do problema do que como a soluçáo.

\section{Conclusão}

Em suma, o período de quarenta anos transcorrido entre 1953 e 1993, demonstra tanto estabilidade quanto mudanças na política americana. As estruturas e instituiçōes que governam o processo político também manifestam esses dois aspectos. As instituiçóes fornecem muitas possiblidades de acesso político como, também, muitos pontos de veto. $\mathrm{Na}$ ausência de maiorias poderosas ou de grande consenso, elas tendem a impedir o desenvolvimento, em larga escala, de políticas públicas coerentes. Em geral, com relação à sociedade, as instituiçóes políticas têm se mostrado mais abertas, mais democráticas e mais diferenciadas. Isso ajuda a intensificar a legitimidade, mas pouco contribui para solucionar os problemas. E os problemas que necessitam soluçáo - sejam ou não afetados pelas políticas públicas do governo - parecem ser mais terríveis atualmente do que há quatro décadas e menos suscetíveis às inequívocas políticas estabelecidas. As dúvidas estáo mais evidentes do que nos anos 50, na medida que aumentam a complexidade dos problemas e as suas imunidades provenientes das respostas diretas das políticas públicas. Nos anos 50, a mitologia do é posstiel fazer fazia parte do credo americano. Atualmente, se diz: o que se pode fazer, se é que alguma coisa pode ser feita?

\section{Notas}

1 Ver Thomas E. Mann, Unsafe at any margin: interpreting congressional elections. Washington, American Enterprise Institute, 1978; David R. Mayhew, Congress: the electoral connection. New Haven, Yale University Press, 1974.

2 Anthony King \& Giles Alston, Good government and the politics of high exposure. In: The Bush presidency: first appraisals. Colin Campbel e Bert A. Rockman (eds.), Chatham, New Jersey, Chatham House, 1991.

3 Citado in Richard L. Berke, For Clinton, plenty of work is left. The New Tork Times, Aug. 8, 1993, p.22. 
4 Fred I. Greenstein, The bidden-band presidency: Eisenhower as leader. New York, Basic Books, 1982.

5 Ruy A. Teixeira, The disappearing American poter. Washington, The Brookings Instituition, 1992 , p.9.

6 Joel D. Aberbach \& Bert A. Rockman, Clashing beliefs within the executive branch: the Nixon administration bureaucracy. American Political Science Review, 70, Jun. 1976, p.456-468.

7 Joel D. Aberbach \& Bert Rockman, Change in U.S. Federal Executive: from Nixon to Reagan to Bush. Comunicação apresentada na International Political Science Association Research Committee on the Structure and Organization of Government Conference sobre Gopemance in an era of skepticim: administrators and polititians, Stockholm, Sweden, Sept. 16-18, 1982.

8 Jack L. Walker, Mobilizing interesting groups in America: patrons, professions, and social movements. Ann Arbor, University of Michigan Press, 1991.

9 Edward G. Carmines \& James A. Stimson, Race and the transformation of American politics. Princenton, New Jersey, Princenton University Press, 1989.

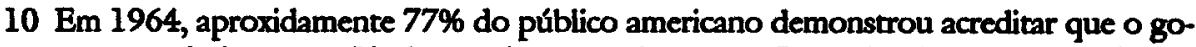
verno poderia ser confível na maior parte do tempo. Por volta de 1980 este número caiu para 26\%, enquanto o nível de confiança do público no governo fluruou de alguma forma. É evidente que dois pontos exerceram profunda influéncia na confiança do público com relaçăo ao governo. Um, foi a combinaçăo do desagradável envolvimento no Vietnã (em 1968 a taxa de confiança caiu 15\%); com o caso Watergate, que arruinou a presidência de Nixon. Entre 1972 e 1976, a confiança no governo caiu de 54\% para $35 \%$. Portanto, no período que abrange o desastroso envolvimento americano no Vietnă, o episódio Watergate e a renúncia de Nixon, a confiança caiu cerca de $42 \%$. O outro fator diz respeito aos dificeis momentos económicos relacionados à percepçáo de uma fraca atuação da liderança. No decurso dos anos $\mathbf{8 0}$, o nível de confiança cresceu cerca de $10 \%$, mas decresceu ao final da década, até as eleiçōes de 1992. Ver Teixeira, p.31-33.

11 Seymour Martin Lipset, Political man: the social bases of Politics, ediçäo atualizada e ampliada, Baltimore: Johns Hopkins University Press, 1981. Ver especialmente, capitrulos 7 e 8.

12 Os năo votantes nảo alterariam os resultados, mesmo que votassem. Esta falta de vantagem partidária é bem documentada e a literatura sobre o tema está resumida em Jerry W. Calvert \& Jack Gilchrist, Suppose they held an election and almost everybody came! PS: Political Science and Politics, 26, Dec. 1993, p.695-700.

13 Ver Teixeira, p.71-74.

14 Edith R. Hornor (ed.), Almanac of the 50 States: basic data profiles with comparative tables. Palo Alto, CA, Information Publications, 1993, p.412. Os números do censo de 1990 registram aproxidamente $\mathbf{2 0 0}$ milhóes de individuos brancos (de descendência europtia direta), aproximadamente 49 milhóes de descendéncia africana ou asiárica, entre outras, e mais 22 milhöes de origem hispânica, a maioria mexicana. 
15 Excelente sintese e explicação do fenómeno de coesāo partidária, especialmente em nivel da elite é encontrada em David W. Rohde, Parties and leaders in the postreform bouse. Chicago, University of Chicago Press, 1991.

16 Ver Martin P. Wattenberg, The decline of American political parties, 1952-1988. Cambridge, MA, Harvard University Press, 1990.

\section{Walker, Mobilizing Intarest Groups.}

18 Um artigo em The New rork Times descreve este fenómeno de labby das bases populares, atualmente observado de forma ampla. O artigo ressalta que: "Nos tiltimos anos, os lobbistas têm evitado uma aproximaçäo direta com relaçáo às bases populares. A meta 6 persuadir eleitores comuns a funcionarem como seus advogados ... Utilizando técnicas desta era eletronica, os lobbistus podem atualmente atingir e recrutar rapidamente milhares de americanos. Muitos legisladores dizem que os lobbistus têm se tornado tão hábeis que suas táticas mudaram a forma de agir do Congresso". Joel Brinldey, Cultivating the grass roots to reap legislative benefits, The New York Times, Nov. 1, 1993, p.Al, B8.

19 Terry M. Moe, The politicized presidency. In: The new direction in American politics, John E. Chubb \& Paul E. Peterson (eds.). Washington, The Brookings Institution, 1985, p.235-272.

20 A luta entre os grupos internos pelo controle da burocracia tobservada, por exemplo, em Joel D. Aberbach \& Bert A. Rockman, Mandates or mandarins? Control and discretion in the administrative state, Public Administrution Revion, 48, p.606-612, Mar./Apr. 1988; Joel D. Aberbach, Keoping a watelful eye: the politios of congressional oversight. Washington, The Brookings Institution, 1990; Robert Spitzer, President and Congreas: excecutipe begennony at the crostroads of American Gopermment. New York, McGraw-Hill, 1993; Charles Tiefer, The semi-soperoign presidency. Westview, Boulder, Co, a sair em 1994. A última citaģao reflete a visăo de um veterano do alto escalăo da Camara dos Deputados.

21 Ver John Holusha, A profitable xerox plans to cut staff by 10.000. The New Tork Times, Dec. 9 1993, p.Cl-C5

22 Relatado ao autor por Robert Reischauer, diretor do U.S. Congressional Budget Office, em conversa pessoal, jun. 1993.

23 Aproximadamente 35 milhöes de pessoas reputam estar sem cobertura de seguro saúde. Ver Alissa J. Rubin, Reinvention of health care is key to Clinton Overhaul. Congressional Quarterly, Mar. 13 1993, p.595-600.

\section{Resumo}

Neste artigo é discutido o desenvolvimento da política americana tendo em vista as transformaģöes ocorridas ao longo das últimas décadas. Procurará contrastar amplamente a política americana como se apresentava em $1953 \mathrm{com}$ a dos dias atuais. As transformaçoes a serem abordadas referem-se às que afetam a composiçăo, participaçäo e alinhamento do grande público em uma sociedade de massa; as que tratam da natureza das instituiģóes políicas e 
governamentais americanas $\mathrm{e}$ as elites; às que influenciam a natureza dos problemas enfrentados pelo governo americano e a perspectiva de tratá-los com eficiência.

\begin{abstract}
This article discusses developments in american politics, focusing on changes that have occurred over the course of the last few decades. It will broadly contrast what American politics looked like in 1953 with how it looks today. The changes I shall focus on are those affecting the composition, participation and political alignment of the mass public; those dealing with the nature of U. S. political and governing institutions and elites; and, those, influencing the nature of the problems with which the U.S. government is faced and the prospects of effectively dealing with them.
\end{abstract}

Bert A. Rockman é professor do Departamento de Ciência Política da Universidade de Pittsburgh (EUA).

Palestra feita pelo autor em 10 de agosto de 1993 no IEA.

Tradução de Célia Sobral. O original em inglês - Politcs in the United States: Trends Through Four Decades, 1953-1993 - encontra-se à disposiçáo do leitor no IEA para eventual consulta. 